\title{
Liquidity and Profitability Analysis: A case study of Delta Brac Housing Finance Corporation Limited.
}

\author{
Sohel Mehedi \\ Department of Accounting and Information Systems (AIS), University of Rajshahi. Rajshahi-6205, Bangladesh.
}

\begin{abstract}
This paper tries to observe the liquidity position and the profitability of Delta Brac Housing Finance Corporation Ltd. during the study period. The study is based on secondary data. Secondary data were collected from the audited financial statements and liquidity statements of DBH for the year 2008-2009 to 2012-2013. During the study period, current ratio, quick ratio, super quick ratio, cash ratio and net working capital position are so poor which are not reached the conventional standard. The profitability ratios of DBH such as net interest income ratio, NOPAT ratio, net profit ratio, return on total assets ratio, return on capital employed ratio and return on equity capital ratio are highly satisfied and covered stakeholders interest during the study period. Net operating profit after tax ratio is proved that the DBH has good control over operating expenses. So the researchers comment regarding the liquidity condition of $D B H$ is unacceptable and the profitability condition of DBH is appreciable during the study period.
\end{abstract}

\section{Introduction:}

Economic development has been phased with the emerging of business organization . Our basic needs such as food, cloth, housing facilities, medical facilities, education and employment opportunities have been increased with the development of business world. Bank and Non bank financial organization have been playing important role in the development of Bangladesh. As a Non-bank financial organization, Delta Brac Housing Finance Corporation Limited has been made contribution in the development of real-estate business. DBH can operate in all the areas that a Non-bank financial institution is allowed to do business. It has only been focusing in real- estate financing. It is considered pioneer and market leader in the private sector housing finance. DBH has provided two types of product such as- Loans and Deposits to its customers. It is accelerating saving, forming national capital, stimulating economic growth and improving living standard. It has a very good credit rating and receiving highest credit rating of "AAA" for 7 consecutive years. This is indicated relative safety, security and strength of a financial institution which is relevant to its depositors and customers. It is ensured continuous efforts to expand home ownership in the country.

\section{Historical Background of DBH:}

Delta Brac Housing Finance Corporation Limited was established in 1996 and commenced its operation in 1997. It was established as an international Joint Venture to promote real estate financing in private sector. In initial stage, there were 5 promoters out of which 3 were local and 2 were international promoters. Three local promoters were- Delta Life Insurance Company Limited, Brac \& Green Delta Insurance Company Limited. International promoters were- HDFC \& IFC. Initially the company was formed as a private limited company. In 2008, the company became a public limited company and enlisted in Dhaka Stock Exchange and Chittagong Stock Exchange. Now general public hold $24.52 \%$ ordinary shares of DBH.

\section{Objectives of the Study :}

This study will try to present the entire scenario of liquidity and profitability of Delta Brac Housing Finance Corporation Limited. The specific objectives of the study are:

- To find out the liquidity position of DBH during the period under study .

- To evaluate overall profitability of DBH during the period under Study.

- To be given suggestions in the light of analysis and findings.

\section{Methodology of the Study:}

This study is mainly based on secondary data. Secondary data are collected from the various sources like journals, annual reports, published books, research works, bulletin board and web side of DBH Ltd. The collected data have been analyzed and interpreted by using some statistical tools like Average, Standard deviation, Co-efficient of variation and T- test method. The period of the study is covered five years from 20082009 to $2012-2013$. 


\section{Analysis and Findings}

Liquidity means the ability of a firm to meet its current or short-term obligation when it becomes due. Customers, Lenders and Suppliers are most interested in current liquidity, but also focus on overall pre-tax profitability and net worth of the company which result of future liquidity.

Liquidity is obviously of crucial importance to the financial stability of a firm. Due to the Mismanagement, the firm's liquidity position shows unable to pay its debt and the result in corporate bankruptcy. On the other hand, large volume of liquid assets strengthen the firm liquidity position, reduce risk ness, but also reduce the overall profitability. The liquidity management is determined firm's ability to survive in the business world.

Working capital management is the bundle of Gross working capital and Net working capital. Gross working capital refers to the firm's investment in current assets. Current assets are those assets which can be converted into cash within an accounting year.

Net working capital refers to the difference between current assets and current liabilities. Current liabilities are those liabilities which are to be paid within an accounting year. Net working capital can be positive or negative. When current assets exceed current liabilities, the balance is considered as positive net working capital. A negative net working capital occurs when current liabilities are in excess of current assets. The negative working capital means a negative liquidity which proves to be harmful for the firm's reputation.

The working capital should be just adequate to the needs of the business firm. The efficient liquidity management expert can easily avoid two danger points of investment in current assets. Excessive investment in current assets should be avoided because it reduces the operating efficiency and profitability of the firm. On the other hand, inadequate amount of working capital can make threaten to solvency of the firm because it focuses inability to meet current obligation of the firm. It is noted that working capital management is absolutely a qualitative aspect. That's why, the management is responsible for taking an initiative action in order to protect a risk-return trade off. To examine the liquidity position of $\mathrm{DBH}$, the following aspects have been made :

Table No: 1

(Figure in million )

\begin{tabular}{|l|l|l|l|l|l|}
\hline \multirow{2}{*}{ Current Assets } & \multicolumn{5}{|c|}{ Financial Year } \\
\cline { 2 - 5 } & $2008-2009$ & $2009-2010$ & $2010-2011$ & $2011-2012$ & $2012-2013$ \\
\hline Cash \& Bank balance & 2606.56 & 2851.43 & 2102.80 & 1300.11 & 7116.75 \\
\hline Money at call \& short notice & 71.94 & - & 60.00 & 1650.00 & - \\
\hline Investments & 269.19 & 803.49 & 356.38 & 348.12 & 335.60 \\
\hline Loan \& Advances & 1058.21 & 1702.29 & 2173.80 & 4071.71 & 4723.16 \\
\hline Other Assets & 117.79 & 74.50 & 101.83 & 146.06 & 215.50 \\
\hline A .Total Current Assets & 4123.69 & 5431.71 & 4794.81 & 7516.00 & 12391.01 \\
\hline Current Liabilities & \multicolumn{5}{|l|}{} \\
\hline $\begin{array}{l}\text { Borrowing from other banks \& } \\
\text { financial institutions }\end{array}$ & 1004.23 & 1740.65 & 965.47 & 1197.25 & 1938.36 \\
\hline Deposits & \multicolumn{5}{|l|}{} \\
\hline Provisions \& other Liabilities & 487.38 & 3113.40 & 3270.94 & 4343.79 & 5661.06 \\
\hline B. Total Current Liabilities & 122.78 & 824.67 & 982.37 & 1642.01 & 1881.94 \\
\hline Net Current Assets (A-B) & 1614.39 & 5678.72 & 5218.78 & 7183.05 \\
\hline Total Assets & 2509.30 & $(247.01)$ & $(423.97)$ & 332.95 & 9481.36 \\
\hline Net Assets & 16385.68 & 22048.79 & 24500.52 & 27640.74 \\
\hline Total Equity & 14771.29 & 16370.07 & 19281.73 & 20457.69 \\
\hline
\end{tabular}

Source : Annual reports of Delta Brac Housing Finance Corporation Limited for the period from 20082009 to 2012-2013.

Table No : 2

\begin{tabular}{|c|c|c|c|c|c|c|c|c|c|c|}
\hline \multirow[t]{2}{*}{ Particulars } & \multicolumn{5}{|c|}{ Financial Year } & \multirow[b]{2}{*}{$\mathrm{AV}$} & \multirow[t]{2}{*}{ SD } & \multirow[t]{2}{*}{$\mathrm{CV}$} & \multirow{2}{*}{$\begin{array}{c}\mathrm{T} \\
\text { Value }\end{array}$} & \multirow{2}{*}{$\begin{array}{c}\text { Significance } \\
\text { Level }\end{array}$} \\
\hline & $\begin{array}{l}2008- \\
2009\end{array}$ & $\begin{array}{l}2009- \\
2010\end{array}$ & $\begin{array}{l}2010- \\
2011\end{array}$ & $\begin{array}{l}2011- \\
2012\end{array}$ & $\begin{array}{l}2012- \\
2013\end{array}$ & & & & & \\
\hline $\begin{array}{l}\text { Current } \\
\text { Ratio }\end{array}$ & 2.55 & 0.95 & 0.92 & 1.04 & 1.31 & 1.35 & 0.68 & 0.50 & 4.413 & 0.012 \\
\hline $\begin{array}{l}\text { Quick } \\
\text { Ratio }\end{array}$ & 1.72 & 0.57 & 0.56 & 0.59 & 0.84 & 0.86 & 0.49 & 0.57 & 3.853 & 0.018 \\
\hline $\begin{array}{l}\text { Super } \\
\text { Quick } \\
\text { Ratio }\end{array}$ & 0.22 & 0.08 & 0.07 & 0.28 & 0.05 & 0.14 & 0.10 & 0.71 & 3.033 & 0.039 \\
\hline $\begin{array}{l}\text { Cash } \\
\text { Ratio }\end{array}$ & 0.18 & 0.08 & 0.06 & 0.05 & 0.05 & 0.08 & 0.04 & 0.50 & 3.412 & 0.027 \\
\hline $\mathrm{N} \mathrm{W} \mathrm{C}$ & $\begin{array}{l}2509.3 \\
0\end{array}$ & $(247.01)$ & $\begin{array}{l}(423 . \\
97)\end{array}$ & 332.95 & 2909.65 & $\begin{array}{l}101 \\
6.18\end{array}$ & $\begin{array}{l}1577.2 \\
7\end{array}$ & 1.55 & 1.441 & 0.223 \\
\hline
\end{tabular}


Source: Annual reports of Delta Brac Housing Finance Corporation Limited for the period from 20082009 to 2012-2013.

Interpretation has been made based on Table -1 and Table -2. All the relevant ratios are calculated in Table No2 to test the liquidity position of DBH.

Current Ratio - current ratio establishes the relationship between current assets and current liabilities. Standard of current ratio is 2:1. Average, Standard deviation, Co-efficient of variation of current ratio is respectively 1.35, 0.68 , and 0.50 . To be conducted one sample t-test using SPSS with a view to finding whether there is no significant difference between the current ratios of DBH in the different years. The result shows that t value is 4.413 which is significant at 0.012 levels. This represents that there is significant difference between the current ratios of DBH in different years. Finally we can comment that the current ratio is not satisfactory during the study period.

Quick Ratio - Quick ratio establishes the relationship between quick or liquid assets and current liabilities. Normally Standard of quick ratio is 1:1. Average, Standard deviation, Co-efficient of variation of quick ratio is respectively $0.86,0.49$, and 0.57 . To be conducted one sample t-test using SPSS with a view to finding whether there is no significant difference between the quick ratios of DBH in the different years. The result shows that $t$ value is 3.853 which is significant at 0.018 levels. This represents that there is significant difference between the quick ratios of DBH in different years. Finally we can comment that the quick ratio is not satisfactory during the study period.

Super Quick Ratio -Super Quick ratio establishes the relationship between cash + marketable securities and current liabilities. This ratio indicates that the firm is able to make payment quickly. It is a more rigorous and penetrating test of liquidity position of a firm. Average, Standard deviation, Co-efficient of variation of super quick ratio is respectively 0.14, 0.10, and 0.71 . To be conducted one sample t-test using SPSS with a view to finding whether there is no significant difference between the super quick ratios of DBH in the different years. The result shows that $t$ value is 3.033 which is significant at 0.039 levels. This represents that there is significant difference between the super quick ratios of DBH in different years. Finally we can comment that the super quick ratio is not satisfactory during the study period.

Cash Ratio - cash ratio indicates the relationship between cash and current liabilities. It measures the firm's instant or at a time payment capacity. It ensures the positive cash balance of a firm. Average Standard deviation, Co-efficient of variation of cash ratio is respectively $0.08,0.04$, and 0.50 . To be conducted one sample t-test using SPSS with a view to finding whether there is no significant difference between the cash ratios of DBH in the different years. The result shows that $t$ value is 3.412 which is significant at 0.027 levels. This represents that there is significant difference between the cash ratios of DBH in different years. Finally we can comment that the cash balance is positive in all the years during the study period.

Net Working Capital - net working capital is the difference between current assets and current liabilities. Average , Standard deviation, Co-efficient of variation of net working capital is respectively 1016.18, 1577.27 and 1.38. To be conducted one sample t-test using SPSS with a view to finding whether there is no significant difference between the net working capital of DBH in the different years. The result shows that $t$ value is 1.441 which is significant at 0.223 levels. This represents that there is no significant difference between the net working capital of DBH in different years. Finally we can comment that the net working capital of DBH is not satisfactory during the study period. It is visible that the treasury department of DBH is not able to determine optimum risk-return trade off. 
Graph-1: Current Ratio.

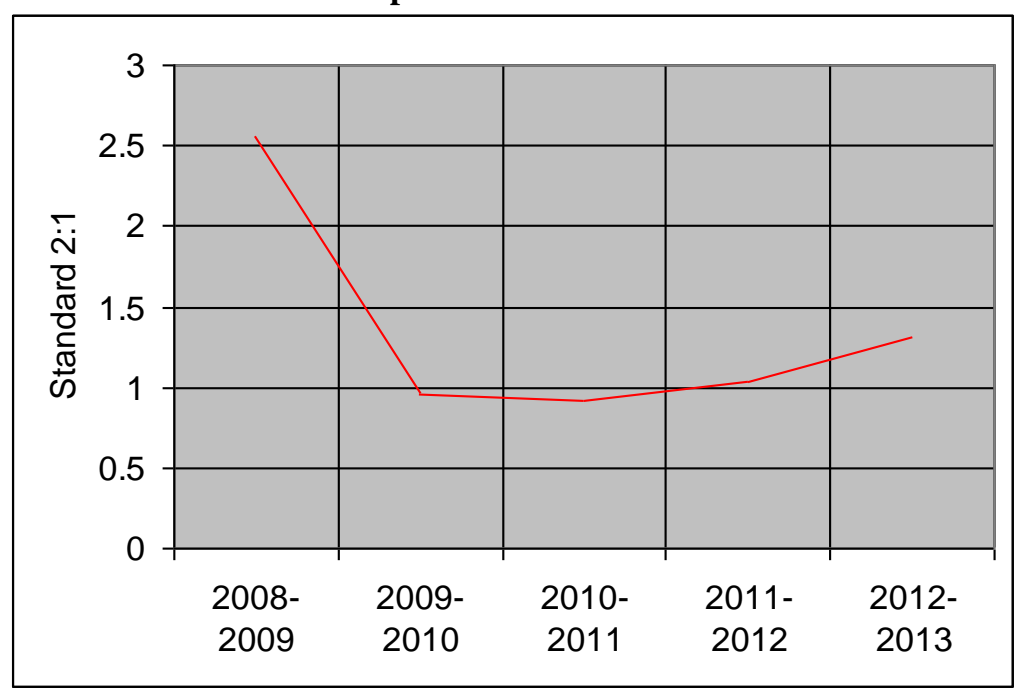

Graph-2: Quick Ratio.

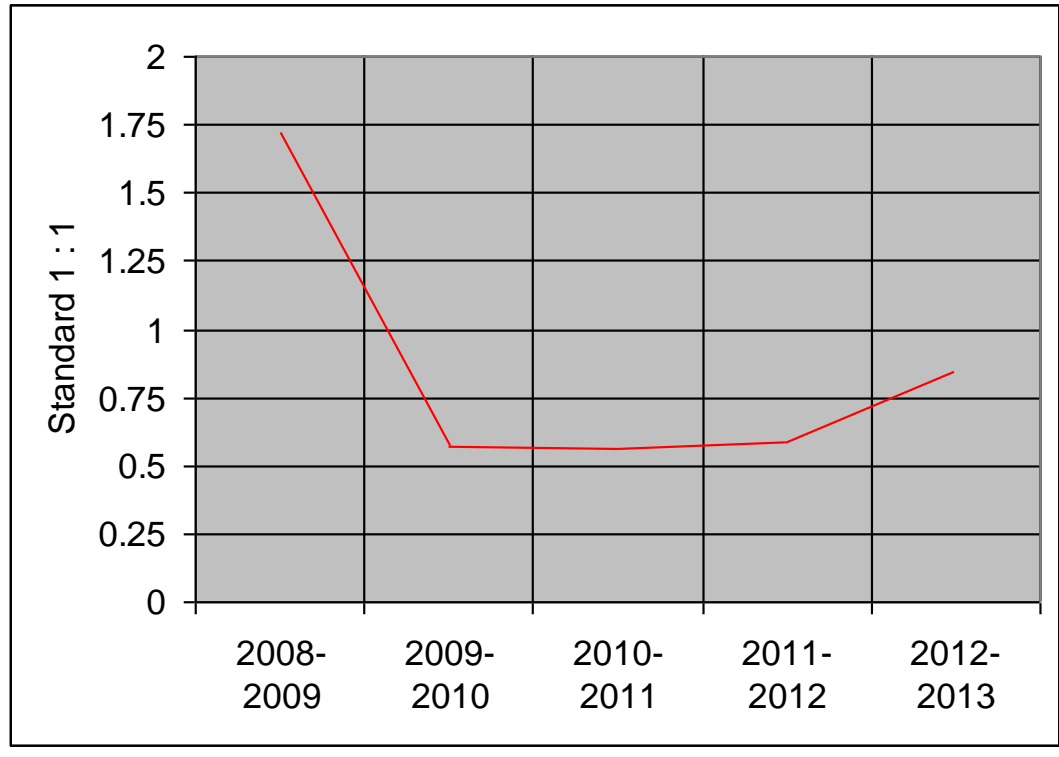

Graph-3: Are the actual claims on Liquidity position of DBH ?

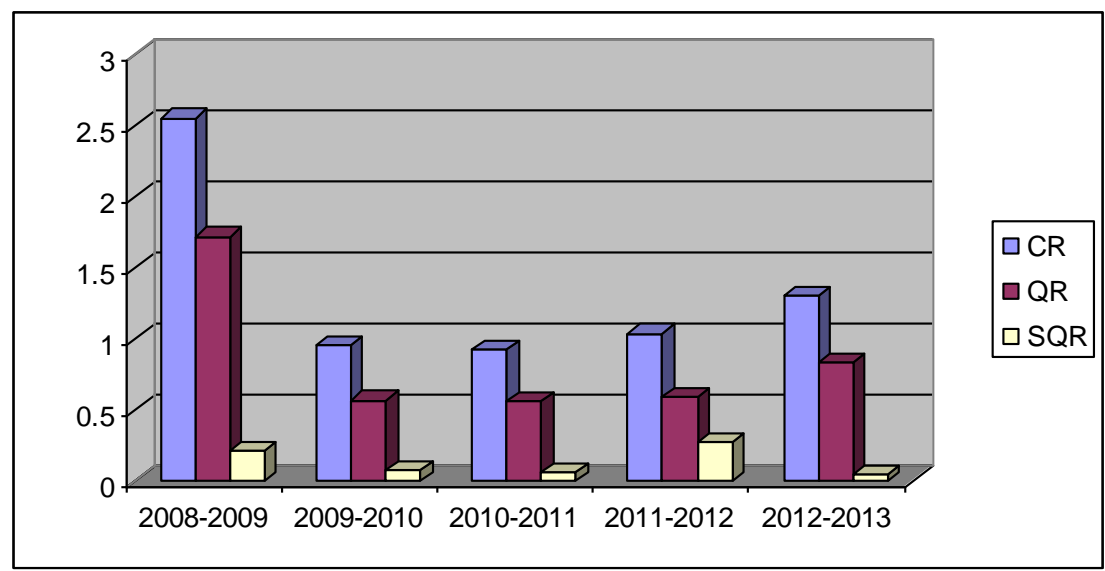


Profitability- Profitability is the profit earning capacity of a firm. A firm should earn profit to survive in the business world. Profit is the difference between revenues and expenses over a period of time. It can be measured in terms of calculating profit related ratios. Profitability ratios are calculated to measure the operating efficiency of the firm. Profitability measurement is an important guide to proper and effective management of a firm. All the stakeholders are interested in profitability of a firm. Creditors want to get interest and repayment of principal regularly. Owners want to get a required rate of return on their investment. All interested parties are satisfied only when the firm earns required profit. That's why profitability analysis is a powerful tool to measure the managerial efficiency of a firm. It is noted that the profit is the ultimate output of a number of policies and decisions which measures the managerial effectiveness and indicates the destination of a firm. To examine the profitability of $\mathrm{DBH}$, the following aspects have been made :

Table No : 3

( Figure in million )

\begin{tabular}{|l|l|l|c|l|l|}
\multicolumn{2}{|c}{ Current Assets } & \multicolumn{5}{c|}{ Financial Year } \\
\cline { 2 - 5 } & $2008-2009$ & $2009-2010$ & $2010-2011$ & $2011-2012$ & $2012-2013$ \\
\hline Interest Income & 1864.56 & 2309.54 & 2689.32 & 3458.38 & 4331.99 \\
\hline Net Interest Income & 561.93 & 763.68 & 889.81 & 982.61 & 1295.01 \\
\hline $\begin{array}{l}\text { Operating Expenses } \\
\text { Profit before tax and interest }\end{array}$ & 171.18 & 246.01 & 269.05 & 259.19 \\
284.93 \\
\hline $\begin{array}{l}\text { Profit before tax and other } \\
\text { provisions }\end{array}$ & 431.34 & 2185.85 & 2706.38 & 3240.47 & 4045.64 \\
\hline Profit before tax & 790.73 & 996.22 & 869.44 & 1131.60 \\
\hline $\begin{array}{l}\text { NOPAT( Net Operating Profit } \\
\text { After Tax ) }\end{array}$ & 432.96 & 639.99 & 906.88 & 764.70 & 1008.67 \\
\hline Net profit after tax & 248.02 & 454.67 & 572.83 & 499.93 & 650.67 \\
\hline
\end{tabular}

Source: Annual reports of Delta Brac Housing Finance Corporation Limited for the period from 20082009 to 2012-2013.

Table No: 4

(Figure in million)

\begin{tabular}{|c|c|c|c|c|c|c|c|c|c|c|}
\hline \multirow[t]{2}{*}{ Particulars } & \multicolumn{5}{|c|}{ Financial Year } & \multirow[t]{2}{*}{ AV } & \multirow[t]{2}{*}{ SD } & \multirow[t]{2}{*}{$\mathrm{CV}$} & \multirow[t]{2}{*}{ T-Value } & \multirow{2}{*}{$\begin{array}{c}\text { Significance } \\
\text { Level }\end{array}$} \\
\hline & $\begin{array}{l}2008- \\
2009\end{array}$ & $\begin{array}{l}2009- \\
2010\end{array}$ & $\begin{array}{l}2010- \\
2011\end{array}$ & $\begin{array}{l}2011- \\
2012\end{array}$ & $\begin{array}{l}2012- \\
2013\end{array}$ & & & & & \\
\hline Net Interest Ratio & 0.30 & 0.31 & 0.33 & 0.28 & 0.29 & 0.30 & 0.019 & 0.06 & 35.107 & 0.000 \\
\hline $\begin{array}{l}\text { Operating Expense } \\
\text { Ratio }\end{array}$ & 0.09 & 0.11 & 0.10 & 0.07 & 0.06 & 0.08 & 0.020 & 0.25 & 9.274 & 0.001 \\
\hline NOPAT Ratio & 0.13 & 0.19 & 0.21 & 0.14 & 0.15 & 0.16 & 0.034 & 0.21 & 10.675 & 0.000 \\
\hline Net Profit Ratio & 0.12 & 0.13 & 0.18 & 0.11 & 0.12 & 0.13 & 0.027 & 0.20 & 10.637 & 0.000 \\
\hline Return on total Assets & 0.11 & 0.10 & 0.11 & 0.11 & 0.12 & 0.11 & 0.007 & 0.06 & 34.785 & 0.000 \\
\hline $\begin{array}{l}\text { Return on Capital } \\
\text { Employed }\end{array}$ & 0.12 & 0.13 & 0.14 & 0.15 & 0.17 & 0.14 & 0.019 & 0.13 & 16.507 & 0.000 \\
\hline Return on Equity & 0.21 & 0.23 & 0.28 & 0.18 & 0.21 & 0.22 & 0.037 & 0.16 & 13.412 & 0.000 \\
\hline
\end{tabular}

Source: Annual reports of Delta Brac Housing Finance Corporation Limited for the period from 20082009 to 2012-2013.

Interpretation has been made based on Table $-1,3$ and Table -4 . All the relevant ratios are calculated in Table No-4 to test the profitability of DBH.

Net Interest Income Ratio - Net interest income ratio represents the relationship between net interest income and interest income from actual operation. Average, Standard deviation, Co-efficient of variation of net interest income ratio is respectively $0.30,0.019$ and 0.06 . To be conducted one sample t-test using SPSS with a view to finding whether there is no significant difference between the net interest income ratios of DBH in the different years. The result shows that $t$ value is 35.107 which is significant at 0.000 levels. This represents that there is significant difference between the net interest income ratios of DBH in different years. We observe that the net interest income ratio of DBH is positive all the years during the study period. Finally we can comment that the net interest income ratio of DBH is satisfactory during the study period.

Operating Expense Ratio -Operating expense ratio is a yardstick of operating efficiency. Operating expense ratio represents the relationship between operating expense and interest income from actual operation. Average, Standard deviation, Co-efficient of variation of operating expense ratio is respectively 0.08, 0.020 and 0.25 . To be conducted one sample t-test using SPSS with a view to finding whether there is no significant difference between the operating expense ratios of DBH in the different years. The result shows that $t$ value is 9.274 which is significant at 0.001 levels. This represents that there is significant difference between the operating expense ratios of $\mathrm{DBH}$ in different years. We observe that the operating expense ratio of $\mathrm{DBH}$ is maintained minimum 
level which delivered positive operating profit and net profit all the years during the study period. Finally we can comment that the operating expense ratio of DBH is satisfactory during the study period.

NOPAT (Net Operating profit After Tax) Ratio -NOPAT ratio measures the actual operating performance of a firm. NOPAT ratio represents the relationship between operating profit after tax and interest income from actual operation. Average, Standard deviation, Co-efficient of variation of NOPAT ratio is respectively $0.16,0.034$ and 0.21 . To be conducted one sample t-test using SPSS with a view to finding whether there is no significant difference between the NOPAT ratios of DBH in the different years. The result shows that $\mathrm{t}$ value is 10.675 which is significant at 0.000 levels. This represents that there is significant difference between the NOPAT ratios of DBH in different years. We observe that the NOPAT ratio of DBH is presented positive balance all the years during the study period. Finally we can comment that the NOPAT ratio of DBH is satisfactory during the study period.

Net Profit Ratio - Net profit ratio represents the relationship between profit after tax and interest income from actual operation. Average, Standard deviation, Co-efficient of variation of net profit ratio is respectively 0.13 , 0.027 and 0.20 . To be conducted one sample t-test using SPSS with a view to finding whether there is no significant difference between the net profit ratios of DBH in the different years. The result shows that $t$ value is 10.637 which is significant at 0.000 levels. This represents that there is significant difference between the net profit ratios of DBH in different years. We observe that the net profit ratio of DBH is positive all the years during the study period. Finally we can comment that the net profit ratio of DBH is satisfactory during the study period.

Return on Total Assets - Return on total assets ratio represents the relationship between profit before tax and interest and total assets. This ratio is used to analyze the ability of the firm's management to know how far as possible to operate total assets for the purpose of generating profit . Average, Standard deviation, Co-efficient of variation of return on total assets ratio is respectively $0.11,0.007$ and 0.06 . To be conducted one sample t-test using SPSS with a view to finding whether there is no significant difference between the return on total assets ratios of DBH in the different years. The result shows that $\mathrm{t}$ value is 34.785 which is significant at 0.000 levels. This represents that there is significant difference between the return on total assets ratios of DBH in different years. We observe that the return on total assets ratio of DBH is carried on positive percentage (maximum 12\% and minimum 10\%) all the years during the study period. Finally we can comment that the return on total assets ratio of DBH is satisfactory during the study period.

Return on Capital Employed - Return on capital employed ratio represents the relationship between profit before tax and interest and capital employed. This ratio is the most crucial profitability ratio which is used to determine return on total capital of a firm. Average, Standard deviation, Co-efficient of variation of return on capital employed ratio is respectively $0.14,0.019$ and 0.13 . To be conducted one sample t-test using SPSS with a view to finding whether there is no significant difference between the return on capital employed ratios of DBH in the different years. The result shows that $t$ value is 16.507 which is significant at 0.000 levels. This represents that there is significant difference between the return on capital employed ratios of DBH in different years. We observe that the return on capital employed ratio of DBH is carried on positive percentage ( maximum-17\% and minimum 12\%) all the years during the study period. Finally we can comment that the return on capital employed ratio of DBH is satisfactory during the study period.

Return on Equity - Return on equity ratio represents the relationship between net profit after tax and shareholders equity. A return on shareholders equity is calculated to see the profitability of owner's investment. Average, Standard deviation, Co-efficient of variation of return on equity ratio is respectively $0.22,0.037$ and 0.16 . To be conducted one sample t-test using SPSS with a view to finding whether there is no significant difference between the return on equity ratios of DBH in the different years. The result shows that $t$ value is 13.412 which is significant at 0.000 levels. This represents that there is significant difference between the return on equity ratios of DBH in different years. We observe that the return on equity ratio of DBH is carried on positive percentage ( maximum-28\% and minimum 18\%) all the years during the study period. Finally we can comment that the return on equity ratio of DBH is satisfactory during the study period. 
Graph-4: Net Profit After Tax and Net Operating Profit After Tax.

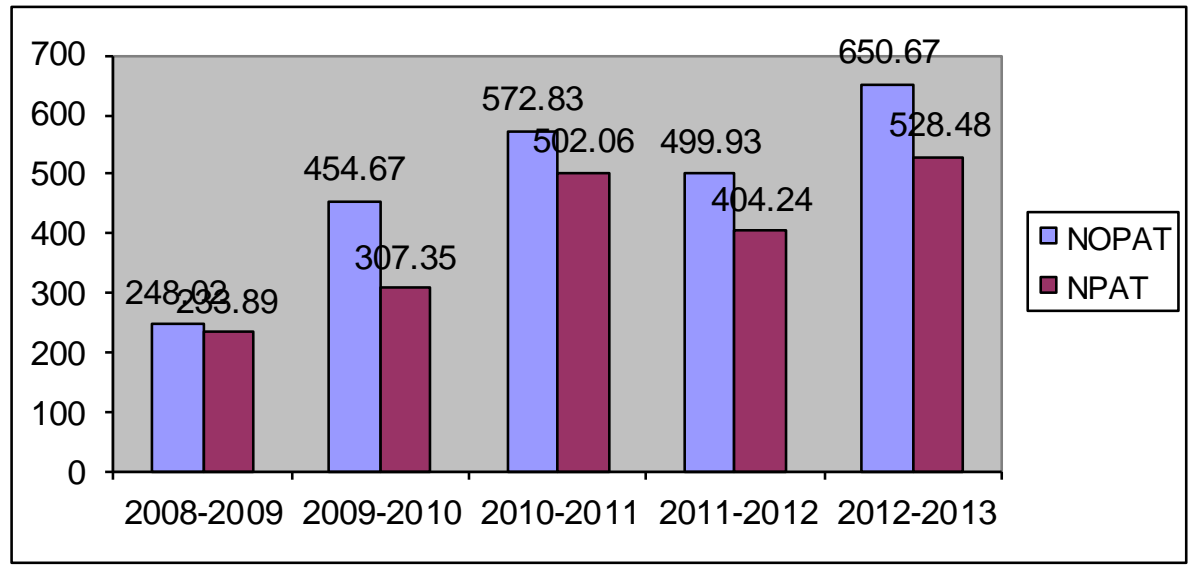

Graph-5: Percentage of Return on Capital Employed and Equity Capital.

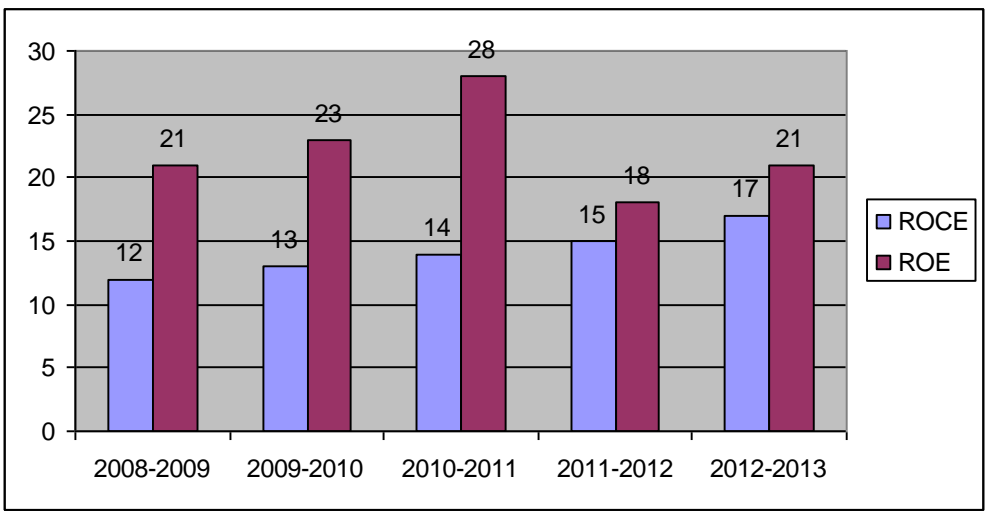

\section{Suggestions to be given in the form of conclusion:}

We can conclude that the liquidity management of DBH could not introduce an efficient management practices in the handling of net working capital management. The net working capital indicates the overall liquidity position of the firm. During the study period, net working capital of DBH shows positive balance in three years and negative balance in two years. The current ratio and the quick ratio are not covered the conventional standard to maintain the optimum level of liquidity. The scenario of profitability is very good looking during the study period. The return on capital employed and the return on equity obtain required rate of return which is maximized stakeholders interest. The net operating profit after tax shows required percentage all the years during the study period which refers to tight control in operating expenses. The study reveals that there are problems in the liquidity management. The Treasury Department of DBH should be given emphasis in the field of working capital management in order to maintain a level of liquidity which is ensured a risk-return trade off (optimum liquidity and maximum profit).

\section{Bibliography}

[1]. Pandey, I. M., (2006-2007) Financial Management, Vikas Publishing House Pvt Ltd., Delhi.

[2]. Khan, M.Y. and Jain, P.K, (2002) Financial Management, prentice Hall of India, New Delhi.

[3]. Banerjee, B., (Tenth Revised Edition) Cost Accounting, The World Press Private Limited., Calcutta.

[4]. Kothari, C.R., (Second Edition-2005) Research Methodology-Methods \& Techniques, Published by New Age International (P) Ltd.,

[5]. The Institute of Chartered Accountants of Bangladesh, Study Manual-Business And Finance.

[6]. Delta Brac Housing Finance Corporation Ltd., Annual Audited Financial Statements and Liquidity. Statement from 2008-2009 to 2012-2013.

[7]. Abedin, M.M.M.,(2011), Liquidity and Profitability of Grameen phone Ltd. in Bangladesh: An Evaluation, Rajshahi University Journal of Social Science And Business Studies, Volume -19, RU Publication No-151, ISSN: 1681-0716.

[8]. Islam, M.A.,(2011), Liquidity and Profitability Analysis : A case Study of Rajshahi Jute Mills Ltd., Rajshahi University Journal of Social Science And Business Studies, Volume -19, RU Publication No-151, ISSN: 1681-0716.

[9]. Rahman, T. and Hossain, M.M.,(2013), Analysis of Investment Cost : The case of Islamic Banks in Bangladesh, Journal of Islamic Economics Banking and Finance, Volume -9 Number -1, ISSN:2070-4658.

[10]. Bari, M.A.,(2004), Foreign Direct Investment in Bangladesh : Some Selected Issues, Rajshahi University Journal of Business Studies, Volume -1. 